\title{
Access to Credit by Smallholder Female Farmers in Ho Municipality, Ghana
}

\author{
Grace Denny Doku (Corresponding author) \\ Department of Agro Enterprise Development, Faculty of Applied Sciences and Technology \\ Ho Technical University, P. O. Box HP 217, Ho-Ghana \\ E-mail: avliaman@yahoo.com \\ Joyce Mamle Mawusi Obubuafo \\ Department of Agro Enterprise Development, Faculty of Applied Sciences and Technology \\ Ho Technical University, P.O. Box HP 217, Ho-Ghana \\ E-mail: mamlejo1@yahoo.com \\ Margaret Aba Sam Hagan \\ Department of Agropreneurship, Faculty of Entrepreneurship and Enterprise Development \\ Kumasi Technical University, P.O. Box 854, Kumasi \\ E-mail: aba_hagan13@yahoo.com
}

Received: March 20, 2020

Accepted: April 17, 2020

Published: May 20, 2020

doi:10.5296/wjbm.v6i1.17113 URL: https://doi.org/10.5296/wjbm.v6i1.17113

\begin{abstract}
The study investigated the access to credit facilities by smallholder female farmers in the Ho municipality. Data for the study was collected from 58 randomly sampled smallholder female farmers in the Ho Municipality of Ghana. Primary data was the main source of data used for the study. Descriptive statistics including frequencies, percentages and graphs as well as inferential statics were used to analyze the data collected from the female farmers. Result of the study revealed that most of the female farmers within the municipality are aware of various sources they can access credit facility. However, several factors were identified to be militating against their access to credit. These factors include: High interest rate, lack of collaterals, low level of education was some of the factors identified. In conclusion, there is
\end{abstract}




\section{Macrothink}

World Journal of Business and Management

ISSN 2377-4622 2020, Vol. 6, No. 1

the need to encourage some of the financial institutions to support these farmers with concessionary loans. It is also recommended that Non-governmental organizations operating in the financial sector should come to the aid of these female farmers.

Keywords: Credit, Smallholder farmers, Women, Agriculture, Ho 


\section{Introduction}

The accessibility to credit is a major problem to production in many developing countries. Making credit available to farmers is particularly a major challenge in most of these developing countries. According to Amoa-Mensah (2013), although informal credit market operates widely in rural areas, many lenders typically give very high interest rates thus inhibiting the rural people from investing in productive income generating activities. To curb this problem however, the government established the agricultural development bank in the mid-1960s. The banks interest rates are lower than those offered by commercial banks: 19\% for maize farmers and 22\% for other producers (AgriFin, 2012). However, its performance has been characterized by low repayment rates. As of 2010, only $29 \%$ of its lending went to agriculture (AgriFin, 2012). It is however noticed that the scope of operation of the agricultural development bank and their condition favour only the middle to upper class. While in Ghana, about $57 \%$ of the populace live in rural areas and are mostly engaging in peasant farming with farm holding less than 2 hectares (MoFA, 2007). According to Essien, Arene and Nweze (2013), for a farmer to derive benefit from any institutional credit, the size of the loan, the process of granting such loan, timeliness in disbursement and repayment are important, apart from level of education, marital status and family size. Rural Ghana is served primarily by numerous rural and community banks (RCBs), but only $9 \%$ of its lending is disbursed for agriculture, forestry and fishing (AgriFin, 2012). This situation has attracted the attention of the Ghanaian government and this has led to it creating special mechanisms to expand the access of credit in Ghana such as the stanbic/AGRA loan guarantee program which was signed in march 2010, the collateral registry on February 1, 2011 and the establishment of the export development investment trust fund (EDIF), now EXIMBANK, based on the parliamentary Act 582. In spite of all these policies instituted by the government of Ghana, there seem to be no remarkable improvement in credit accessibility by small holder farmers in the Ho municipality of Ghana. A major challenge facing many developing countries especially in Africa is devising appropriate development strategies that capture financial services to small scale farmers who constitute about $70 \%$ of the population (Oriatu, 2010).

A credit facility is a type of loan made in a business or corporate finance context, including revolving credit, term loans committed facilities, letter of credit and most retail credit accounts. Although there are quite a number of credit facilities in the Ho municipality, small holder farmers complain of lack of funds to expand their economic activities. The study sought to examine access to credit facilities by smallholder female farmers in the study area.

\section{Literature Review}

In Ghana, about $63 \%$ of the total populations are rural dwellers according to Central Bureau of Statistics, (1986). These people live in a vicious cycle of low income. According to the 1993 statistics survey, as reported by Dr. Oti-Boateng-government statistician about $90 \%$ of the rural dwellers live far below the poverty line and lack of credit facilities has contributed to the low income in the rural areas. This therefore, calls for financial institutions, which will help mobilize savings in the rural areas and grant them in a form of credit to the farmers. 


\subsection{Agricultural Policies in Developing Countries}

Agricultural policies in Developing Countries which were written in 1992 concerns the savings, borrowing and investment behavior of the household irrespective of the type of financial market the household faces. According to Tornell and Westermann (2003), the farmers most at time have no resources to save and if even they have anything at all, their potential to save is very low. As a result, having access to credit to channel into investment is a challenge. One needs to have savings which enables him to have access to credit for investment. This implies that, investment has a direct relationship with credit. Thus, if the farmer is given credit, he can use it to expend his/her agriculture activities. Besides, with the use of the credit in hand, the farmer can increase his/her productivity and for that matter his income levels. This will result in improvement in standard of living of the farmer. The theory also implies that, an efficient and appropriate rural financial institution can tap the rural resources into savings and channel them into investable funds (Ellis \& Flannery, 1992).

\subsection{Formal and Informal Sectors}

Ellis and Flannery (1992) defined credit as a sum of money in favor of the person to whom control over it is transferred and that, credit itself, if not capital, can be used, among other things, to make investment. Credit may be formal or informal. The informal sector largely consists of individuals such as traders, landlords or farmers who lend money as business. They are characterized as being usurious and in position of considerable power due to lack of competition, although some will dispute that (Olomola \&Yaro, 2015; Poulton et al., 2010). Formal credit channels are those bound by the large regulations of a country and they include private banks, state-owned banks and registered co-operative (Ellis \& Flannery, 1992).

According to Garland et al. (2005), credit may do a private good in the sense that, it is excludable and subtractable, but these attributes are not necessarily sufficient to make it attractive to private suppliers. This is because; the credit market combines the problems of imperfect information and risk.

\subsection{Government Subsidies to Small-Scale Farmers}

To enable rural farmers and entrepreneurs to obtain credit, there has been an argument that government should subsidize rural credit. However, Olomola and Yaro (2015) pointed out that subsidized loans often end up in the hands of the relatively rich people with broader economic interest. Two World Bank, OECD studies on Mexico, Pakistan and the Philippines, found out that, of the bank funds provided in these countries, only 25-50\% was estimated to have contributed to agricultural development. Instead of providing credit itself at subsidized rate and thereby reducing the opportunities for the development of a functioning private credit system, the public sector should focus on reducing the risk that individual lenders face (Olomola \& Yaro, 2015).

This, therefore, calls for a sustainable financial scheme, which should not rely on external source or subsidies. Ellis and Flannery (1992), reported that, in order to achieve sustainable rural credit, some countries have set up rural credit scheme with objective to make rural credit not reliant on ever increasing subsides to cover losses and not dependent on foreign 
donors. There is the need for self-sustaining rural financial system by savings mobilization in the rural areas to ensure rural financing. This means that, the people in the rural areas should mobilize their own savings, which will serve as the bedrock of rural financing. This means minimal government intervention and because of this, Fletschner (2008) have observed that donors, both North and South-based NGO's are funding co-operative credit institutions which rely on savings mobilization. Some, such as Benin's rural saving and loans or Bank for Agricultural and Agricultural Co-operatives (BAAC's) scheme of Bangladesh, are outside the public sector entirely, whilst other such as Ghana's Rural Banks have minority government participation.

The generation of funds from savers is considered a key feature of self-sustaining credit institution. It is felt that a strong saving base reduces the reliance on external funding. Also, savers and borrowers are after the same people at different points in time in the community thereby reducing information cost of transactions. Again, it is considered that, people tied to an institution for both saving and borrowing are less likely to default (Awunyo-Vitor, 2012). This means that, because the institution that is set up to mobilize savings belong to the people of the community, there is the less likelihood that, they will default in payment. Yaro (1992), therefore, cited an example of a successful credit scheme in Indonesia and Thailand where over a very short period of time, it has been possible to finance lending largely out of voluntary rural savings. From the foregoing analysis, therefore, it can be said that, in order to achieve sustainable credit scheme for rural agricultural development to ensure a balance between urban and rural development, there must be a self-sustaining credit scheme, which calls for saving mobilization (Awunyo-Vitor, 2016).

Awunyo-Vitor and Abankwah (2012) has observed that, the financial system is very crucial in accelerating the rural development. Also, credit is very much more than just input especially for farmers in developing countries whose revenue are very low to spur up any significant improvement in their production system. Thus, harnessing the banking system for development has long been recognized in Ghana and various ways and means have been sought and tried on how to harness banking to support agriculture so that food and raw materials for manufacturing could be produced in abundance to feed the people. Also, Dr. Agama, in his address to the chartered institute of Bankers at their 1995 annual dinner, observed that, the need for credit facilities is highly felt in the rural areas since they form the main foundation upon which any meaningful economic development programme can be based. Again, in talking about the importance of credit to rural development, Opoku-Afriyie (1997) observed that, the scarcity of credit is considered as one of the disincentives and obstacles to efficient and rapid agriculture development.

In the same vein, Owusu-Acheampong (1986) also observed that agricultural credit could play a very important role in rural development. According to him, for rural development to be accelerated there must be a credit scheme to support agriculture which is the main form of occupation in the rural areas. However, according to a survey by Aluko and Ajayi (2018), the most common source of credit for rural farmers has been the non-institutional or the private sector credit which Ellis and Flannery (1992) called the informal sector. This means that, financial institutions, which Ellis and Flannery (1992) called the formal sector are not much 
prepared to grant credit to the rural dwellers, hence, they resort to the non-institutional source of credit which constitute $78 \%$ of the total credit. According to the Institute of Statistical, Social and Economic Research (ISSER report, 1992), this may be due to the fact that, either the people have lost confidence in the institutional credit scheme or that the traditional banking institutions are not prepared to offer credit to the rural dwellers.

It has been observed that investors are not satisfied with services they received from the traditional banks, especially the desired rate of returns on whatever investment they have made with banks. In addition, most of the savers need a little money to turn themselves around but do not get from the Banks (Awunyo-Vitor et al., 2012). Bank customers need to provide collateral securities to be able to obtain loans to do whatever projects they intend undertaking. Hence farmers are not able to make big time investment to enable them get the collateral the banks require. This observation has also been made by Ashta, Couchoro, and Musa (2014). To them, credit institutions granting loans require collateral security which the small- scale farmers may not have and this limits their loans acquisition.

In some instances, bureaucratic procedures in the acquisition of credit from the financial institutions drive the farmers away. It is to solve these problems that the rural bank concept came into being. According to the ISSER, report (1992), it is to improve the credit source for farmers and rural entrepreneurs that, the Rural Bank system was introduced in Ghana in 1976. According to the same report, the establishment of rural banks has led to a decline in the proportion of commercial and secondary banks' loans and advances since 1985. This means that, the rural bank system in Ghana is gradually becoming a sustainable source of rural financing. This observation buttresses Ellis and Flannery (1992) observation that sustainable rural credit is that one that is generated from rural savings mobilization. This is why Eyifah(2010) observed that, the challenges facing the rural banking system is to make the people living in the rural areas have confidence in the rural banking system for all their monetary transactions.

However, by March, 1991, data from the Bank of Ghana showed that out of the 122 existing rural banks at that time, 98 had become distressed and were not able to refund depositors money on demand. Bank of Ghana had to come to the rescue of these banks. As at January, 1994, Bank of Ghana had used the tax payers' money to pay to depositors of the distressed Rural Banks an amount of $\phi 611$ million in order to preserve the confidence of the depositing public in the rural banks (Donaldy, 2017). This observation shows that, the rural banks have not lived up to expectation and therefore, in order to serve as an instrument of rural development, a lot has to be done by these banks.

This means that, if the rural banks are not well organized to cater for the needs of farmers, capital needed for rural development will be transferred from the rural areas to the urban areas by the traditional commercial banks. The refusal of these banks to grant credit facilities to the rural dwellers may be attributed to the low level of repayment of credit granted to them. This low level of repayment can also be a reason why some of the rural banks have become distressed. For the banks to continue granting loans to the farmers there must be a good recovery system. This requires good administrative work on the part of the banks and better 
understanding on the part of the borrowers or rural dwellers.

It is because of this that Lele (1974) asserted that, the credit delivery and recovery and therefore, it's administration to both the lender (banks) and the farmer (borrower) have been beset with problems which have given the agricultural sector and for that matter small-scale food crop farmers a headache in organizing credit programmes. According to Beckett-Camarata (2009), the primary cause of low repayment is that farmers spend large proportion of their incomes on semi luxury items like school fees, religious activities, imported food stuffs and clothing. This means that loans granted to the rural dwellers are not used as intended but rather used for other secondary matters which show why there is low credit recovery among the rural dwellers. Therefore, a good recovery performance required the credit institutions should have legal tools which would permit them to take rapid action against defaulters as observed by Cleaver (1997). Koomson, Annim, and Peprah (2016) also pointed out that, a short repayment period encouraged grant payment. Also, to Udry (1994), informal sanctions can be used to persuade individuals to repay loans.

The Agricultural Development Bank (ADB) in their Book "Agricultural credit progress in Ghana" (1975) commented on the concept of Rural Banking in Ghana as follows; Despite the fact that Ghana's economy was heavily dependent on Agricultural sector, with small-scale farmers contributing about $90 \%$ of all agricultural output, the small-scale farmers' aid to agricultural sector was left to the exploitative money lenders to further worsen the plight of the small-scale farmers. Attempts to alleviate the plight of these farmers and increase agricultural production were done through the formation of co-operations and other associations such as credit union and money lenders, to provide credit and other facilities. Unfortunately, such measures did not achieve any significant result. In an attempt to assist the agricultural sector, the Agricultural Development Bank (ADB) was established in 1965 which was originally a unit of the Bank of Ghana to assist farmers. Its performance over the past have only affected a small portion of the farmers. It was further regrettable to note that, ADB even behaved like the commercial Banks which provided a variety of services to serve the interest of large and medium size enterprise and resource-based companies. The small-scale farmers were generally neglected and left to the mercy of informal sector intermediaries like money lenders, "susu" operators, who charge a high rate of interest. Even commercial Banks tap resources from the rural areas and channel them into trading and other activities in the urban areas, thus neglecting the rural community. This was because commercial Banks found it risky and unprofitable to lend to rural communities who engage in small-scale activities.

The commercial banks which mobilized all available savings in the country devoted about $10 \%$ of their loan portfolio to agriculture and nearly, all this was taken up by relatively large commercial farmers. The indications were that, the Banks would not change their style of lending in the foreseeable future, mainly because they have found their present operations sufficiently profitable without getting involved in Rural lending which required more work and involve high risks.

\subsection{Problems of the Rural Banking System}

Rural banking has had their share of problems. Budastra (2008) outlined some of the 
problems as lack of skilled and good quality staff, financial maladministration and fraud and irregularities on the part of some staff and directors, weak internal controls and accounting systems, irregular submission of prudential returns and the absence of an effective apex body to provide technical service to rural banks. These problems have necessitated the need for the closure of some rural banks (Daily Graphic, February 6, 1996) and by June 1994, 19 rural banks which had become distressed were closed down (Owusu-Antwi \& Antwi, 2010). Dawelbait (2011) stressed that, the performance of rural banks in terms of loans recovery is disappointing. From 1986 to 1990, she said, the average recovery rate was around $41.1 \%$ meaning that the defaulting rate was around $58.6 \%$. This implies that customers demand for funds through borrowing and withdrawal of deposits cannot be met on time.

William (1989), commenting in his book "Informal credit market and its implications for Financial Policy" on "the mishap" of Rural Banks said that, there were crucial factors influencing credit repayment rates in a number of Rural Banks. He urged that if more trained people were employed by rural banks, each expert would have helped to ensure efficient recovery.

Focusing our attention on the attitude of rural folks, Acheampong (1986) had this to say, "The institutions (Banks) in Ghana are facing the problem of misapplying their borrowed credit facilities for purposes other than those for which the loans were granted. This problem has put some farmers before court and others have had their property sold to offset what they owned the bank" (Ghana Today, 2000).

So far, the researcher has noted that among the problems, the most prevailing ones are lack of skilled staff, mismanagement and fraud on the part of management and the inability of farmers to pay back the loan in time.

Although the Rural Banks were set up to fill the vacuum created by the lack of credit facilities in the rural area, there is a gap with respect to the effect of credit schemes on Rural Banks on production and income of small-scale farmers and rural people as discovered in this literature review.

\section{Methodology}

The study area is Ho Central Municipality in the Volta Region of Ghana. The study made use of primary data collected from small-holder female farmers in the study area. In all, a total of Fifty-eight (58) respondents were sampled for the study. The simple random sampling technique was employed in selecting the smallholder farmers for the study. A primary source of data provides first-hand testimony or direct evidence concerning atopic under investigation. Primary data were obtained directly from the field through the administration of questionnaires and face-to-face interview. The questionnaires used in this research included a mixture of open-ended and closed-ended-questionnaires which were administered to the farmers. The analysis of data gathered was done in two facets, first by collating quantitative responses with the Statistical Package for Social Sciences (SPSS) analytical tools. Descriptive statistics such as mean, mode and median as well as tables and graphs were used to organize and summarize the data. 


\section{Al Macrothink}

\section{Results and Discussion}

\subsection{Socio Economic Characteristics of the Respondents}

\subsubsection{Age of Respondents}

The modal age group of the respondents was between $41-50$ years $(41.4 \%)$, followed by 51-60 years $(24.1 \%)$, with $34.5 \%$ falling within the age categories of 31-40 years and 21-30 years $(8.6 \%)$ and the last which is, $5.2 \%$ for 61 years and above as shown in Table 1 below. The spread of age category is evident that the farming is normally done by the aged in the study area which is a true reflection of a typical Ghanaian agriculture.

Table 1. Demographic characteristic of the respondents

\begin{tabular}{|c|c|c|c|}
\hline Variable & Sub-level & Frequency & Percentage \\
\hline \multirow{5}{*}{ Age } & $21-30$ & 5 & 8.6 \\
\hline & $31-40$ & 12 & 20.7 \\
\hline & $41-50$ & 24 & 41.4 \\
\hline & $51-60$ & 14 & 24.1 \\
\hline & 61 and above & 3 & 5.2 \\
\hline \multirow[t]{4}{*}{ Marital status } & Single & 10 & 17 \\
\hline & Married & 26 & 45 \\
\hline & Divorced & 9 & 16 \\
\hline & Widowed & 13 & 22 \\
\hline \multirow[t]{7}{*}{ Educational attainment } & Primary & 4 & 6.9 \\
\hline & JHS & 18 & 31 \\
\hline & SHS & 12 & 20.7 \\
\hline & Vocational & 6 & 10.3 \\
\hline & College & 3 & 5.2 \\
\hline & None & 13 & 22.4 \\
\hline & Missing & 2 & 3.4 \\
\hline \multirow[t]{5}{*}{ Family size } & $1-4$ & 22 & 37.9 \\
\hline & $5-8$ & 24 & 41.4 \\
\hline & $9-12$ & 4 & 6.9 \\
\hline & 13 and above & 6 & 10.3 \\
\hline & Missing & 2 & 3.4 \\
\hline
\end{tabular}

Source: Survey, 2018.

The age of' respondents was found to be very influential when investigating about factors that influence credit constraint condition of small-scale farmers in the study area. The result indicates that the higher the age of the farmers or the older they become, the greater the likelihood of being credit constrained. This might be because the younger farmers are still agile and more receptive to new technologies and activities that will generate income. An 
additional year to the age of the farmer will increase the probability of the farmer being constrained because other financial responsibilities come with age.

\subsubsection{Marital Status of Farmer-Respondents}

Majority (45\%) of the respondents interviewed are married where as $17.5 \%$ of them being single with a few of them being divorced (16\%) and widowed (22\%). This can be concluded that, most of the farmers are married and it may have an influence on their accessibility of credits from financial institution as shown in Tablelabove. Marital status was found to have a positive influence on the probability that a farmer had access to credit. This implies that as one marries, the likelihood of having access to credit increases. It is believed that individuals who are married are more likely to be stable and lenders are likely to view them as more reliable and responsible such that they are less likely to be credit constrained. Hence marital status of the farmer-respondents is important in influencing demand for credit facilities as compare to those farmers who are not married.

\subsubsection{Educational Attainment of Farmer-Respondents}

The results (Table 1) indicate that some of the respondents had no education (22.4\%). 6.9\% out of the 58 respondents interviewed had attained primary education, $31 \%$ representing the majority of the respondents attained education up to the (Junior High School) JHS, 20.7\% had education up to Senior High School (SHS) and a few $10.3 \%$ and 5.3\% of the respondents had vocational and college education respectively with $3.4 \%$ missing. The demand for credit is normally influence by farmer's level of education. There is a higher relationship between farmer's demand for credit and his/her level of education. It was believed that farmer's decision to demand credit improves with increased level of education as they are able to understand and follow policies and procedures of these financial institutions. In a related study by Bee (2007) found level of education to be significantly related to demand for credit in Tanzania. It can be concluded that most of the respondents have received formal education as shown in Table 1 above.

\subsubsection{Family Size of Respondents}

Majority (41.4\%) of the farmers interviewed had a family size of 5-8 members followed by $37.9 \%$ with a family size between 1 and 4 where as $10.3 \%$ of the farmers with a family size from 13 and above persons and 3.4\% not answered in Table 1. The number of persons per the respondent's household as a proxy for family labour exhibit different effects on each group. The number of a person's household has positive effects but is insignificant for other farmers. Thus, family labour contributes to crop productivity of farmers. This study also confirms the findings of similar study by Omonona, Lawal, and Oyinlana, (2010).

\subsubsection{Farm size of Farmer-Respondents}

Out of the 58 farmers interviewed, majority (65.5\%) have farm size of 1 to 5 hectares followed by $19 \%$ with farm size between 6 to 10 hectares with $10.3 \%$ having 11 to 15 hectares and a few (5.2\%) with farm size more than 15 hectares (Table2). The size of farm land owned by a farmer has an influenced on the accessibility of credit from a credit 
institution since it is normally used as a form of collateral for granting out loans. Farm size has a negative and significant relationship with the probability of a farmer being credit constrained. This is because lenders use farm size as an indicator for scale of operation and revenue and consequently farmers' repayment capacity. Lenders therefore tend to offer credit to farmers with larger farm sizes. Alternatively, farmers with larger farm sizes may earn higher revenue and may not need credit, leaving them unconstrained. A hectare increase in farm size would decrease the possibility of a farmer being credit constrained.

Table 2. Farm characteristics

\begin{tabular}{|l|l|l|l|}
\hline Variable & Sub-level & Frequency & Percentage \\
\hline Farm size in hectares & $1-5$ & 38 & 65.5 \\
\hline & $6-10$ & 11 & 19.0 \\
\hline & $11-15$ & 6 & 10.3 \\
\hline & Over 15 & 3 & 5.2 \\
\hline Land tenure & Owner tenant & 23 & 40 \\
\hline & Share tenant & 20 & 34 \\
\hline & Both owner and share tenant & 15 & 26 \\
\hline Farming experience & $1-5$ & 12 & 20.7 \\
\hline & $6-10$ & 14 & 24.1 \\
\hline & $11-15$ & 12 & 20.7 \\
\hline & 16 and above & 19 & 32.8 \\
\hline & Missing & 1 & 1.7 \\
\hline Number of extension visits & $1-2$ & 15 & 29.5 \\
\hline & $3-4$ & 13 & 22.4 \\
\hline & $7-8$ & 2 & 3.4 \\
\hline & 9 and above & 1 & 1.7 \\
\hline & None & 27 & 46.6 \\
\hline & & & \\
\hline
\end{tabular}

Source: Survey, 2018.

\subsection{Farm Characteristics}

\subsubsection{Land Tenure of Farmer-Respondents}

Majority (40\%) of the respondents owned their farm land where as $34 \%$ of the farmers interviewed had a share tenant arrangement on their farm land with $26 \%$ out of the 58 farmers interviewed having both owner and share tenant arrangement (Table 2). The farmers with a share tenant arrangement share their proceeds with the owners of the land in certain proportions (with most of it being a 70-30 arrangement) where as those with both owner and share tenant arrangement own certain portion of their farm land and share cropped certain portion of the remaining farm land. 


\subsubsection{Farming Experience}

Majority of the farmers have been into farming over 16 years $(32.8 \%)$ followed by $24.1 \%$, $20.7 \%, 20.7 \%$ being into farming for 6-10 years, $11-15$ years and 1-5 years respectively with a minimum and maximum of 1 year and 36 years respectively with $1.7 \%$ as those who failed to answer. The study revealed that farming experience has significant positive effect on output for farmers but insignificant effect on the productivity of the credit-constrained farmers. This finding suggests that experience is less likely to contribute to output if the farmer is credit-constrained. It can be inferred that the farmers are very experienced in farming as shown in Table 2 above.

\subsubsection{Number of Extension Visits}

Majority (46.6\%) of the farmers have not received any visits from extension agents where as $25.9 \%, 22.4 \%, 3.4 \%$ and $1.7 \%$ out of the 58 farmers interviewed received 1-2, 3-4, 7-8 and 9 and above extension visits respectively (Table 2). Majority of farmers do not get in touch with extension agents. The study further revealed that access to extension services has a positive effect for those farmers who the extension officers come into contact with. One explanation for this is that some farmers may not have funds to implement recommendations made by the extension officers; therefore, access to extension services would have a positive and significant effect on the productivity of farmers. Despite this, in a one-on-one discussion, about $46.6 \%$ of the farmers reported not having access to an extension service. Based on previous discussion with the Ministry of Food and Agriculture district director of the study area revealed that the district does not have enough extension officers for all the operational areas.

\subsection{Awareness of Credit Facilities}

Out of the 58 farmers interviewed, (69\%) of them indicated they were aware of credit facility in financial institutions for farmers with only a few (31\%) indicating they had no idea financial institutions had such facility for farmers (Figure 1). Out of the $69 \%$ of the farmers who indicated they were aware of the credit facility of the bank, about $25.9 \%$ of them said they have applied for credit from the bank before and the remaining indicated they had never applied for credit. Those few farmer-respondents who said they were not aware said so because they do not belong and attend association meetings and they are not interested in knowing about the credit facilities in the lending/financial institutions. Six (6) of the respondents further elaborated that they are content to borrow from the traders and relatives instead of banks because they don't require collateral as the bases for lending them the money. In addition, they are also share tenant and have no collateral to give so they did not explore the possibilities of borrowing from financial institutions/ sources. For those farmers-respondents who are aware, some of them attended the association meetings and heard from neighbors and friends about credit facilities in the lending/institutions.

However, the awareness of credit services is relatively important for credit available in a particular community. Provision and strengthening of awareness about various credit services influenced the farmers in their credit access (Singh, 2001). This can be attributed to the fact 


\section{Macrothink}

World Journal of Business and Management

ISSN 2377-4622

2020, Vol. 6, No. 1

that the farmers can not readily obtain credit if they are not aware of the contented borrowing from financial institutions available in the area. The results revealed that there were $(31 \%)$ farmer-respondents who are not aware because they do not belong to and attend the any farmer's association meetings so they are just conversant with their personal savings and borrowing from informal sources within the research areas.

\section{Awareness of Credit Facilities}

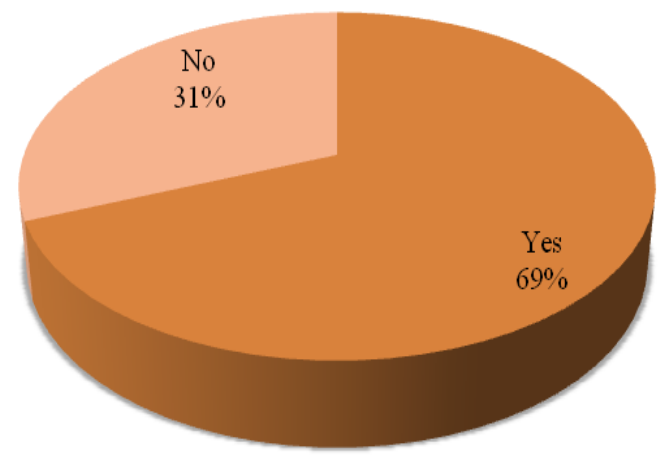

Figure 1. Awareness of credit facilities in the area

Source: Survey, 2018.

\subsection{Nearness of the Financial Institutions to the Farmers}

Majority of farmers interviewed (34.5\%), according to Figure 2 below, said they do not know how far they are from financial institutions. $32.8 \%$ said $6-10 \mathrm{Km}$, and $10.3 \%$ said $11-15 \mathrm{Km}$. $3.4 \%$ they have to cover $16-20 \mathrm{Km}$ and more distance before getting access to credit facilities which is preventing them from acquiring loan facilities, whilst few farmers constitute $(15.5 \%)$ said they are closer $(1-5 \mathrm{Km})$ to financial institutions. Distance to the nearest financial institution had very high relationship with demand for credit facilities. This imply that the shorter the distance to the financial institution the greater the likelihood of farmer demanding financial credit. Therefore, increasing availability of financial institutions resulting in easy access has greater likelihood of increasing demand for credit facilities. This observation supports the findings from the study of Zeller, Diagne, and Mataya (1998) and Bee (2007) on demand for financial credit which indicated that proximity has higher relationship with demand for credit. 


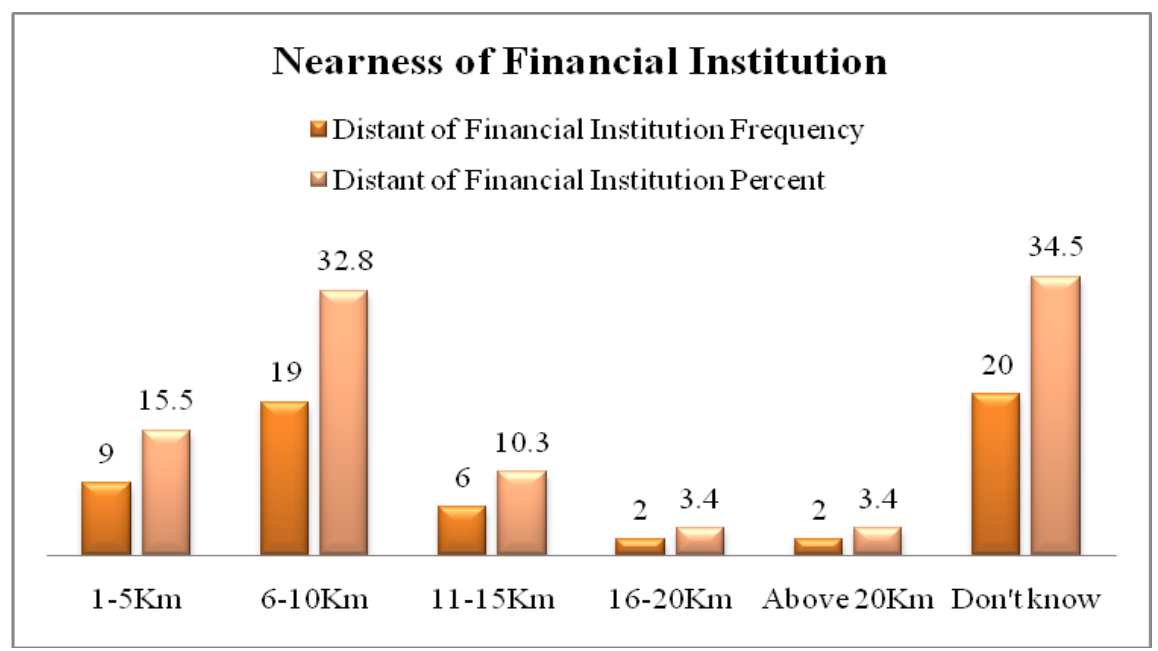

Figure 2. Distant of the nearest financial institution

Source: Survey, 2018.

\subsection{Respondents' Sources of Funding for Production}

Figure 3 shows respondents' access to funds for farm production. Results show that $69 \%$ of all sampled women farmers funded their farm operations from their personal savings. The bank which is the main institution established to provide agricultural credit to farmers contributed only $19 \%$ of the funds while family and friends collectively contributed $8.6 \%$ with money lenders recording the least percentage (3.4\%). Altogether, $91 \%$ of the funds for farming by sampled women farmers came from informal sources. The implication of this finding is that most of the women farmers do not have access to formal sources of agricultural credit despite the existence of credit institutions with mandate to lend to agriculture. This is totally inadequate and there is urgent need to increase credit flow for agricultural production, especially to women farmers. The implication is for policy makers to identify and deliver agricultural credit in places of urgent need such as women in agriculture (women farmers) for increased agricultural productivity in the Municipality.

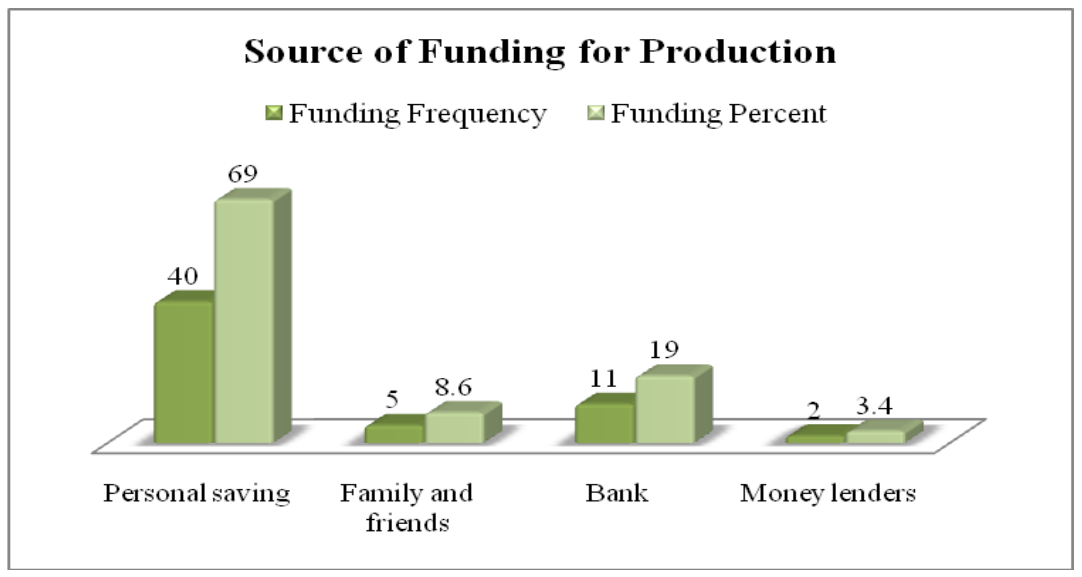

Figure 3. Respondents' source of funds for farm production

Source: Survey, 2018. 


\subsection{Challenges Faced by Farmers in Accessing Credit from Financial Institutions}

The study identified and ranked some of the challenges faced by women farmers in accessing loans and the results are presented in figure 4 below. For the farmers interviewed, collateral requirement on loan is a very pressing challenge. $36.2 \%$ of the farmers interviewed agree that they lack collateral in other to access loan. The study also revealed that the second most pressing challenge affecting the farmers in accessing loans is the cumbersome procedure they have to go through. Patronage of financial institutions by the women farmers is negatively affected by their presence within the research area, cumbersome procedures for opening accounts and loan application procedures. Thus, farmers' access to financial services from various financial institutions can be improved through establishment of more branches and agencies in other communities within the district, and streamlining procedures for accessing their services. The low patronage of financial institution was attributed to tedious operational modalities and the inability of these financial institutions to offer enough agricultural credit to small-scale farmers. The study also revealed that interest rate which recorded $15.5 \%$ has negative effect on the demand of credit in both formal and informal financial institutions in the research area. This implies that high interest rate demanded by the financial institutions prevent farmers from accessing credit facilities in their institutions. This supports the findings of Amonoo et al., (2003), which indicated that there is a negative relationship between interest rate and access to credit. When interest rates are low more small-scale farmers will access credit facilities in other to expand their farm activities resulting in high productivity.

Unrealistic terms and conditions that the farmers would have to meet in order for them to access loan from the financial institution recorded $12.1 \%$.

Lastly, $5.2 \%$ of the farmers interviewed agree that financial institutions normally reduce the amount of loan they apply for. The study on reduction of amount of loan requested by small-scale farmers revealed that, the higher the loan amount, lower the probability for default. This is because with higher loan amount the farmer would be able to purchase all the necessary inputs to increase productivity and consequently increase earnings which can be used to repay the loan required. This result is in contrast with the findings of Ashun (2010), which examines repayment performance beneficiaries of group-based credit programmes in Bangladesh. However, it supports the finding by Jiménez and Saurina (2004) who found repayment to be positively correlated with loan amount.

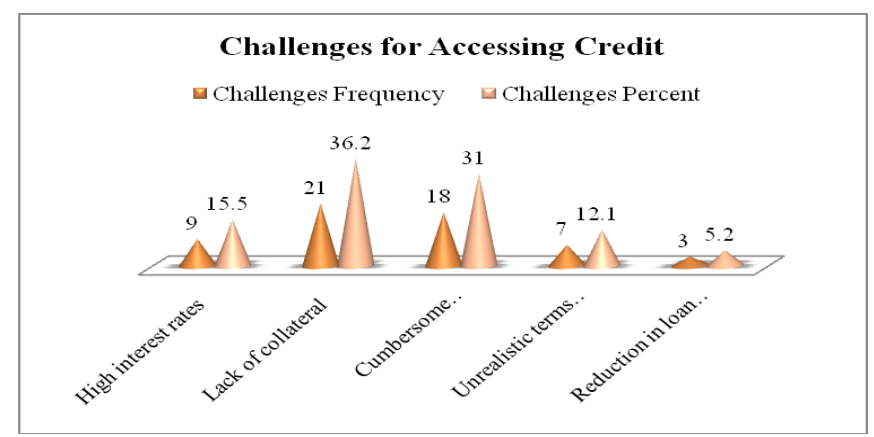

Figure 4. Challenges hindering credit accessibility of respondents

Source: Survey, 2018. 


\section{Macrothink}

\subsection{Effect of Credit Unavailability on Economic Activities of Respondents}

Olomola and Yaro (2015) have found that agricultural credit has positive output and employment effects. Many farmers are poor and trapped in a vicious cycle of poverty because they cultivate small areas of land from which they produce little output, and hence sell only a very small amount, which cannot help in expanding their farms, acquiring new technologies so the cycle continues (Awotide et al., 2015). To break out of the vicious cycle of poverty, credit is essential since it determines access to all the resources the farmers depend on. Awotide et al. (2015) argued that agricultural credit is required not just for agricultural production alone, but also for consumption. This is necessary because it make farmers more productive in their labour input and to help them during the lean periods before and after planting season, during which farmers hardly have enough to eat which affects their productivity.

Respondents were asked to identify their perceived constraints to increased farm production and distribution in the study area that is factors they feel when improved would enable them to produce and sell more of their farm products. Their identified constraints are shown in figure 5below. The data is presented in column graphs with their heights in percentages representing the strengths of the problems.

The women farmers in the study identified the problem of low output/living standard $(51.7 \%)$, inadequate input material (22.4\%), and delay in production (12.1\%), transportation/marketing difficulties (8.6\%), and other problems (5.2) as factors limiting their productivity.

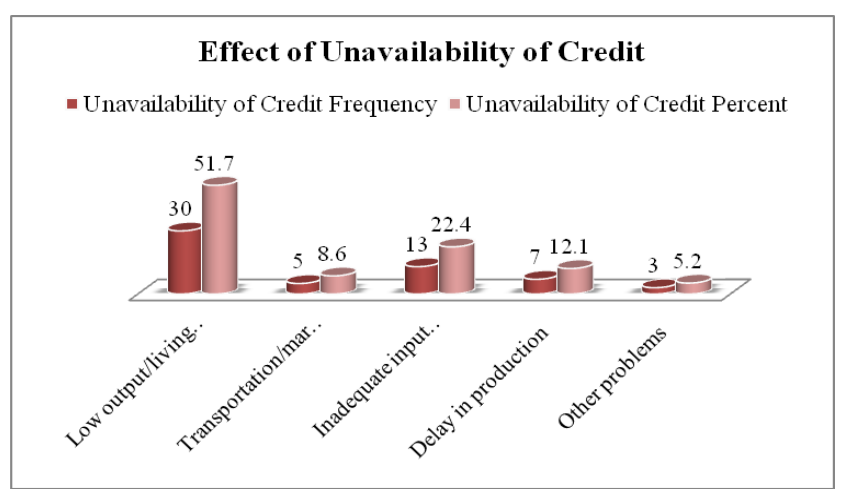

Figure 5. Effects of unavailability of credit on economic activities

Source: Survey, 2018.

\section{Conclusion and Recommendation}

\subsection{Conclusions}

The study focused on accessibility of credit facilities among small-scale farmers in the Ho Central Municipality in Volta Region of Ghana. It looked at the awareness of farmers about credit facilities of financial institutions and also challenges they faced in the course of accessing credit in the research area and its effect on their farm productivity. The factors influencing farmers' access for credit were also analyzed. 


\section{Mll Macrothink}

Out of the 58 farmers interviewed, almost all (69\%) of them indicated they were aware of credit facility in financial institutions for farmers with only a few (31\%) indicating they had no idea financial institution had such facility for farmers (Figure 4.9). Out of the $69 \%$ of the farmers who indicated they were aware of the credit facility of the financial institutions, about $25.9 \%$ of them said they have benefited from the financial institutions in the form of loan and the remaining indicated they had never benefited. A few farmer-respondents who said they were not aware do so because they do not belong to the farmer-based association and also, they do not attend association meetings and they are not interested in knowing about the credit facilities in the financial institutions. Hence, they are not able to expand their farming activities as well as to improve upon their productivity.

For the farmers interviewed, high interest rate on loan is a very pressing challenge. The study revealed that interest rate has negative effect on the demand for credit in both formal and informal financial institutions in the research area.

Also, lack of collateral limits most of the farmers to access loan from financial institutions.32.8\% of the farmers interviewed agree that they lack the collateral requested by financial institutions. Farmer-respondents with collateral securities have a good chance of acquiring bigger loan from financial institutions as compared to those without collateral securities.

The study concludes that lack of access to credit by the female farmers has a dire consequence on their productivity as well as living conditions as per the results $(51.7 \%)$.

\subsection{Recommendations}

The study recommends the following:

1) Government should address the issues of collateral and interest rates on loans for farmers, particularly, female farmers so they can access credit for their farming operations.

2) The issue of low education among female farmers should also be addressed as a matter of urgency as literature shows that it has influence on access to credit.

3) Rural Banks should increase the percentage of their loan portfolio to small-scale farmers to help improve upon their performance.

\section{Acknowledgements}

The authors are especially indebted to Adjah Hiroyuki Deladem of the Department of Agro Enterprise Development of the Faculty of Applied Sciences and Technology, Ho Technical University, Ho Ghana.The authors are also grateful to the respondent small scale farmers in the Ho Central Municipality in the Volta Region and the anonymous reviewers who reviewed the paper.

\section{References}

Acheampong, F. (1986). Common Law Liability of Accountants for Negligence to Non-Contractual Parties: Recent Developments. Dick. L. Rev., 91, 677. Restricted from 
https://heinonline.org/HOL/LandingPage?handle=hein.journals/dlr91\&div=24\&id=\&page=

Agricultural Development Bank. (1975). Agricultural Credit Programmes in Accra, Ghana. ADB Report on (2001.and 2005). Retrieved From https://www.agricbank.com/

AgriFin. (2012). All Smallholder Farmers Prospering in an Interconnected Digital World. Retrieved From https://collaboration.worldbank.org/content/sites/collaboration-for-development/en/groups/ag rifin.html

Aluko, O. A., \& Ajayi, M. A. (2018). Determinants of banking sector development: Evidence from Sub-Saharan African countries. Borsa Istanbul Review, 18(2), 122-139. https://doi.org/10.1016/j.bir.2017.11.002

Amoa-Mensah, J. J., Aubyn, A., Amoah, I., Opoku, C., Amponsah, P., \& Osei- Baah, F. (2013). Challenges Faced by Farmers in Accessing Credit from Rural Banks (Doctoral dissertation). Retrieved from http://www.ir.csuc.edu.gh

Amonoo, E., Acquah, P. K., \& Asmah, E. E. (2003). The Impact of Interest Rates on Demand for Credit and Loans Repayment by the Poor and SMEs in Ghana.

Ashta, A., Couchoro, M., \& Musa, A. S. M. (2014). Dialectic evolution through the social innovation process: from microcredit to microfinance. Journal of Innovation and $\begin{array}{lllll}\text { Entrepreneurship, } & 3(1), & \text { R. } & \text { Retrieved from }\end{array}$ http://www.innovation-entrepreneurship.com/content/3/1/4

Ashun, F. E. (2010). Reducing rural poverty through microfinance intervention: A case study of Lower Pra rural bank limited Shama (Doctoral dissertation, University of Cape Coast). Retrieved from http://hdl.handle.net/123456789/1752

Awotide, B. A., Abdoulaye, T., Alene, A., \& Manyong, V. M. (2015). Impact of Access to Credit on Agricultural Productivity: Evidence from Smallholder Cassava Farmers in Nigeria. A Contributed Paper Prepared for Oral Presentation at the International Conference of Agricultural Economists (ICAE) Milan, Italy August 9-14, 2015. https://doi.org/10.22004/ag.econ.210969

Awunyo-Vitor, D. (2012). Determinants of Loan Repayment Default Among Farmers in BrongAhafo Region of Ghana. Journal of Development and Agricultural Economics, 4(13), 339-445. Retrieved from http://hdl.handle.net/123456789/6107

Awunyo-Vitor, D. (2016). Informal financial market in Ghana: Factors influencing participation by maize farmers. Savings and development, 39(1), 37-58. Restricted from https://www.jstor.org/stable/90002015?seq=1

Awunyo-Vitor, D., \& Abankwah, V. (2012). Substitutes or Complements: Formal and Informal Credit Demand by Maize Farmers in Ashanti and BrongAhafo Regions of Ghana. International Journal of Agriculture and Forestry, 2(3), 105-112. https://doi.org/10.5923/j.ijaf.20120203.05 
Awunyo-Vitor, D., Abankwah, V., \& Kwansah, K. J. (2012). Women Participation in Microcredit and its Impact on Income: A study of Small-Scale Businesses in the Central Region of Ghana. American Journal of Experimental Agriculture, 2(3), 502-515. https://doi.org/10.9734/AJEA/2012/1127

Bank of Ghana Report. (1987). Retrieved From https://www.bog.gov.gh/

Beckett-Camarata, J. (2009). The current impact of the tightening credit market on municipal borrowing costs: A case study. Municipal Finance Journal, 29(4), 77-86.

Bee, F. K. (2007). Rural financial markets in Tanzania: An analysis of access to financial services in Babati district, Manyara Region (Doctoral dissertation). Retrieved from http://hdl.handle.net/10500/1746

Budastra, I. K. (2008). 4. Factors Associated to Rural Households' Access to Financial Services in Rural Lombok, Indonesia. JURNAL AGRIMANSION, 9(2), 96-109. Retrieved From http://agrimansion.unram.ac.id/index.php/Agri/article/view/197

Central Bureau of Statistics of Ghana. (1986). Retrieved from https://www.civicresearchinstitute.com/online/issue.php?pid=4

Cleaver, K. (1997). Rural development strategies for poverty reduction and environmental protection in Africa. In Rural Well-being: From Vision to Action: Proceedings of the Fourth Annual World Bank Conference on Environmentally Sustainable Development, Held at the World Bank and the George Washington University, Washington, DC, September 25-27, 1996 (Vol. 15, p. 195). World Bank Publications. Retrieved from http://documents.worldbank.org/curated/en/254301468739295428/Rural-well-being-from-vis ion-to-action

Daily Graphic. (February 6, 1996). Retrieved From http://www.graphic.com.gh

Dawelbait, F. A. S. (2011). Factors Affecting Women's Access to Agricultural Services and Farm Income in Sennar State (Doctoral dissertation, Sudan Universty of science and technology). Retrieved From http://repository.sustech.edu/handle/123456789/2405

Diagne, A. (1999). Determinants of household access to and participation in formal and informal credit markets in Malawi (No. 583-2016-39679, pp. 1-68). https://doi.org/10.22004/ag.econ.94524

Donaldy, R. (2017). Determinants of Share Pricing of Rural and Community Banks in Ghana. Research Journal of Finance and Accounting, 8(2). Retrieved From https://www.semanticscholar.org/paper/Determinants-of-Share-Pricing-of-Rural-and-Banks-i n-Donaldy/ea561efd902c43ac2cef2dc4024a541fda7f6558

Ellis, D. M., \& Flannery, M. J. (1992). Does the debt market assess large banks, risk: Time series evidence from money center CDs. Journal of Monetary Economics, 30(3), 481-502. https://doi.org/10.1016/0304-3932(92)90008-P

Essien, U. A., Arene, C. J., \& Nweze, N. J. (2013). What determines the frequency of loan 
demand in credit markets among small scale agro-based enterprises in the Niger Delta region of Nigeria? An empirical analysis. Journal of Agriculture and Sustainability, 4(1). Retrieved from https://www.infinitypress.info/index.php/jas/article/view/218

Eyifah, B. O. (2010). Credit risk management of non-bank and banking institutions: a comparative study of teachers' fund financial services and Unique Trust Bank (Doctoral dissertation, University of Cape Coast). Retrieved from http://hdl.handle.net/123456789/3345

Fletschner, D. (2008). Women's access to credit: Does it matter for household efficiency?.American journal of agricultural economics, 90(3), 669-683. https://doi.org/10.1111/j.1467-8276.2008.01143.x

Garland, S. M., Smith, D. B., Thompson, J. A., \& R. J. Nokia of America Corp. (2005). Wireless telemetering access. U.S. Patent Number: USOO6975862B1

Ghana Today. (2nd June, 2002). Retrieved From https://twitter.com/search?q=ghana+today\&ref_src=twsrc\%5Egoogle\%7Ctwcamp\%5Eserp\% 7Ctwgr\%5Esearch

Ghana Today. (5th July, 2000). Retrieved https://www.myjoyonline.com/ghana-news/news.php

ISSER Report. (1992). Retrieved From https://isser.edu.gh/

Jiménez, G., \& Saurina, J. (2004). Collateral, type of lender and relationship banking as determinants of credit risk. Journal of banking \& Finance, 28(9), 2191-2212. https://doi.org/10.2139/ssrn.1233582

Koomson, I., Annim, S. K., \& Peprah, J. (2016). Loan refusal, household income and savings in Ghana: a dominance analysis approach. African Journal of Economic and Sustainable Development, 5(2), 172-191. Retrieved from https://papers.ssrn.com/sol3/papers.cfm?abstract_id=3437549

Lele, U. J. (1974). The roles of credit and marketing in agricultural development. In Agricultural policy in developing countries (pp. 413-449). Palgrave Macmillan, London. Retrieved from https://link.springer.com/chapter/10.1007/978-1-349-63663-1_16

Ministry of Food and Agricultural. (2007). Agriculture in Ghana, Facts and Figures.

OECD. (1999). Agricultural Finance and Credit infrastructure in Transition Economies. In OECD Expert Meeting, Moscow.

Olomola, A. S., \& Yaro, M. (2015). Commercial banks' response to government's financial stimulus for improved agricultural financing in Nigeria (No. 28). International Food Policy Research Institute (IFPRI). https://doi.org/10.35188/unu-wider/2015/042-3

Omonona, B. T., Lawal, J. O., \&Oyinlana, A. O. (2010). Determinants of credit constraint conditions and production efficiency among farming households in Southwestern Nigeria (No. 308-2016-5022, pp. 1-14). https://doi.org/10.22004/ag.econ.95775 
Opoku-Afriyie, K. J. (1997). Promoting enterprises in the wood products subsector in Ghana. Small Enterprise Development, 8(1), 46-55. Retrieved from https://www.ingentaconnect.com/content/papub/sedv/1997/00000008/00000001/art00007

Oriatu (2010). Retrieved From http://www.com.cutestat.com

Owusu-Acheampong, J. H. (1986). Rural credit and rural development in Ghana. Rural development in Ghanaledited by CK Brown. Retrieved From http://agris.fao.org/agris-search/search.do?recordID=US201301408360

Owusu-Antwi, G., \& Antwi, J. (2010). The analysis of the rural credit market in Ghana. International Business \& Economics Research Journal (IBER), 9(8). https://doi.org/10.19030/iber.v9i8.611

Poulton, C., Dorward, A., \& Kydd, J. (2010). The future of small farms: New directions for services, institutions, and intermediation. World Development, 38(10), 1413-1428. https://doi.org/10.1016/j.worlddev.2009.06.009

Singh, B. B. (2001). Challenges to agricultural lending. National Bank News Review, 17. Retrieved From http://hdl.handle.net/10179/1687

Tornell, A., \& Westermann, F. (2003). Credit Market Imperfections in Middle Income Countries (No. w9737). National Bureau of Economic Research. CESifo Working Paper, No. 960. Retrieved From http://hdl.handle.net/10419/76416

Udry, C. (1994). Risk and insurance in a rural credit market: An empirical investigation in northern Nigeria. The Review of Economic Studies, 61(3), 495-526. https://doi.org/10.2307/2297901

Williams, K. (1989). Informal credit market and implication for Financial Policy, New York. World Bank. (2000). Report on financial credit to small-scale farmers and its impact in Ghana. Retrieved From https://www.worldbank.org/

Yaro, J. (1992). Rural Finance in Developing Countries. World Bank's Agricultural Policies working paper. World Bank, Washington D.C.

Zeller, M., Diagne, A., \& Mataya, C. (1998). Market access by smallholder farmers in Malawi: Implications for Technology adoption, agricultural productivity and crop income. Agricultural Economies, 19, 219-229. https://doi.org/10.1016/S0169-5150(98)00027-9

\section{Copyright Disclaimer}

Copyright for this article is retained by the author(s), with first publication rights granted to the journal.

This is an open-access article distributed under the terms and conditions of the Creative Commons Attribution license (http://creativecommons.org/licenses/by/3.0/). 